\title{
Genetic Variability and Host Specialization in the Latin American Clade of Ceratocystis fimbriata
}

\author{
Christine J. Baker, Thomas C. Harrington, Ulrike Krauss, and Acelino C. Alfenas
}

First and second authors: Department of Plant Pathology, Iowa State University, Ames 50011; third author: CABI/CATIE/USDA Project, Centro Agronómico Tropical de Investigación y Enseñanza, 7170 Turrialba, Costa Rica; and fourth author: Departamento de Fitopatologia, Universidade Federal de Viçosa, Minas Gerais, Brazil. Accepted for publication 29 April 2003.

\begin{abstract}
Baker, C. J., Harrington, T. C., Krauss, U., and Alfenas, A. C. 2003. Genetic variability and host specialization in the Latin American clade of Ceratocystis fimbriata. Phytopathology 93:1274-1284.

The Ceratocystis fimbriata complex includes many undescribed species that cause wilt and canker diseases of many economically important plants. Phylogenetic analyses of DNA sequences have delineated three geographic clades within Ceratocystis fimbriata. This study examined host specialization in the Latin American clade, in which a number of lineages were identified using sequences of the internal transcribed spacer (ITS) region of the rDNA. Three host-associated lineages were identified from cacao (Theobroma cacao), sweet potato (Ipomoea batatas), and sycamore (Platanus spp.), respectively. Isolates from these three lineages showed strong host specialization in reciprocal

isolates and were not pathogenic to cacao in inoculation tests. Further evidence of host specialization within the Latin American clade of Ceratocystis fimbriata was demonstrated in inoculation experiments in growth chambers using sweet potato, sycamore, Colocasia esculenta, coffee (Coffea arabica), and mango (Mangifera indica) plants; inoculation experiments in Brazil using Brazilian isolates from cacao, Eucalyptus spp., mango, and Gmelina arborea; and inoculation experiments in Costa Rica using Costa Rican isolates from cacao, coffee, and Xanthosoma sp. Hosts native to the Americas appeared to be colonized by only select pathogen genotypes, whereas nonnative hosts were colonized by several genotypes. We hypothesize that local populations of Ceratocystis fimbriata have specialized to different hosts; some of these populations are nascent species, and some host-specialized genotypes have been moved to new areas by humans.
\end{abstract} inoculation experiments on these three hosts. Six cacao isolates from Ecuador, Trinidad, and Columbia differed genetically from other cacao

Ceratocystis fimbriata Ellis \& Halsted attacks an exceptionally wide range of economically important plants, causing wilt-type diseases, cankers, and rot of storage roots. The fungus usually enters woody plants through wounds. A total of 31 plant species representing 14 families have been confirmed as hosts, including trees such as sycamore (Platanus spp.), mango (Mangifera indica L.), Gmelina arborea Roxb., cacao (Theobroma cacao L.), Citrus spp., coffee (Coffea arabica L.), rubber tree (Hevea brasiliensis (Willd. ex Adr. Juss) Müll. Arg.), Spathodea sp., Prunus spp., fig (Ficus carica L.), poplar (Populus spp.), Acacia spp., and Eucalyptus spp. and root crops such as sweet potato (Ipomoea batatas (L.) Lam.) and edible aroids (Colocasia esculenta (L.) Schott and Xanthosoma spp.) (7). The fungus has a broad geographic range, and various host-associated forms appear to be native throughout North and Latin America as well as Asia (18). A close relative, Ceratocystis albofundus Wingfield, De Beer \& Morris, is native to southern Africa $(40,53)$.

Despite its wide host and geographic ranges, Ceratocystis fimbriata is generally known on each host in only a relatively restricted geographic area (7). For example, mango is reported as a host only in Brazil, even though mango trees are grown throughout northwestern South America and Central America, where the fungus is common on cacao and coffee. Several limited inoculation studies $(4,9,21,23,29,30,38)$ have suggested the existence of host specialization within the Ceratocystis fimbriata complex. However, Webster and Butler (51) concluded that Ceratocystis

Corresponding author: T. C. Harrington; E-mail address: tcharrin@iastate.edu

Publication no. P-2003-0808-01R

(C) 2003 The American Phytopathological Society
Additional keywords: fungal phylogenetics, speciation. fimbriata was a single species because isolates from various hosts were sexually interfertile and morphologically indistinguishable.

Genetic analyses of rDNA sequences and partial sequences of the MAT-2 mating type gene delineate three geographic clades within Ceratocystis fimbriata centered in North America, Latin America, and Asia, respectively (18). Some lineages within these major clades appear to be associated with specific hosts. Barnes et al. (5) found that some of the variation in microsatellite markers among Ceratocystis fimbriata isolates correlated with the plant hosts from which the isolates were collected. Isolates from sycamore in Europe appeared to be distinct from sweet potato and Populus isolates based on random amplified polymorphic DNA markers (43). These observations suggest that genetically distinct groups within Ceratocystis fimbriata may have unique host ranges, but previous inoculation studies used only a few isolates on a few host plants, and no previous study has examined host specialization of Ceratocystis fimbriata within a phylogenetic context.

The aim of this study was to examine phylogenetic relationships and host specialization within the Latin American clade of Ceratocystis fimbriata (18), particularly focusing on isolates from cacao, sweet potato, and sycamore. Isolates from these and other hosts native or exotic to Latin America were used for rDNA-internal transcribed spacer (ITS) sequencing and in a series of inoculation studies.

\section{MATERIALS AND METHODS}

Fungal isolates. Isolates of Ceratocystis fimbriata were obtained primarily from trees showing wilt symptoms or cankers, rotted storage roots or rotted corms, or from culture collections. Representative isolates of the Latin American clade from particu- 
lar hosts were selected for genetic analysis and inoculation studies (Table 1).

ITS sequencing. Genomic DNA for use as template in polymerase chain reactions (PCR) was obtained from mycelium grown in $25 \mathrm{ml}$ of broth (2\% malt extract and $0.2 \%$ yeast extract) at room temperature (approximately $24^{\circ} \mathrm{C}$ ) for 2 weeks. Extraction of DNA followed the method of DeScenzo and Harrington (10). Sequences of the ITS region and 5.8S gene of the rDNA were obtained by PCR amplification of genomic DNA using the primers ITS1F (5'-CTTGGTCATTTAGAGGAAGTAA-3') and ITS4 (5'TCCTCCGCTTATTGATATGC-3') $(16,52)$, following the protocol of Harrington et al. (19), with slightly different cycling conditions, which were an initial denaturation at $94^{\circ} \mathrm{C}$ for $95 \mathrm{~s}$ followed by 35 cycles of denaturation $\left(94^{\circ} \mathrm{C}\right)$ for $35 \mathrm{~s}$, annealing at $52^{\circ} \mathrm{C}$ for $60 \mathrm{~s}$, and extension at $72^{\circ} \mathrm{C}$ for $60 \mathrm{~s}$. Final extension was at $72^{\circ} \mathrm{C}$ for $15 \mathrm{~min}$.

Phylogenetic analysis. Sequences were aligned manually by adding gaps and analyzed using parsimony with PAUP $4.0 \mathrm{~b} 10$ (46). Ceratocystis albofundus isolate C1048 from Acacia mearnsii de Wild. in South Africa was used as the outgroup taxon, and the ingroup was considered monophyletic. Of 676 total characters including gaps, 89 were ambiguously aligned and excluded from the analysis, 150 remaining sites were variable, and of these, 52 were parsimony-informative. Gaps were treated as a fifth character. A maximum parsimony heuristic search was performed with all characters having equal weight. Stepwise addition was used to obtain starting trees, and tree-bisection-reconnection was used. Bootstrap analysis with 1,000 replications of heuristic searches was used to assess support for the internal branches (14).

Inoculation experiments. Because several lineages distinguished by the phylogenetic analysis correlated with host plants from which the isolates were collected, we performed a series of inoculation experiments with isolates from these lineages. Three series of inoculation experiments were performed using varying hosts and isolates in growth chambers at Iowa State University and in outdoor nurseries at Viçosa, Brazil and Turrialba, Costa Rica.

Growth chamber experiments. Three experiments were performed in growth chambers. In the three-host experiment, cacao, sweet potato, and sycamore plants were inoculated with nine isolates from these hosts. In the five-host experiment, sweet potato, sycamore, coffee, and Colocasia plants were inoculated with 13 isolates from various hosts and several different lineages, and mango plants were inoculated with four of those isolates. In a separate cacao experiment, cacao plants were inoculated with 14 cacao isolates of varying ITS sequences to examine variability in pathogenicity among cacao isolates (Table 1).

All plants for growth chamber experiments were grown in pasteurized potting mix containing $25 \%$ peat, $25 \%$ soil, and $50 \%$ perlite. Sycamore (Platanus occidentalis L.) seeds were half-sib progeny from an open-pollinated tree (Sheffield's Seed Company, Locke, NY). Cacao seeds for the three-host inoculation experiment were obtained from pods of a cacao tree grown in a greenhouse at the Iowa State University campus. The cultivar of this cacao plant was unknown, but fruits were smooth, slightly furrowed, yellow, approximately 15 to $20 \mathrm{~cm}$ by $10 \mathrm{~cm}$, and 20 to 40 seeds per pod. Cacao seeds for the cacao inoculation experiment were obtained from pods of cv. Theobahia (Forastero type) from Bahia, Brazil. Sweet potato cuttings were propagated vegetatively from sprouts of a storage root (unknown cultivar, cream flesh and peach skin) obtained from a grocery store in Ames, Iowa. Mango plants were propagated from seeds of mango fruits (unknown cultivar), also obtained from a grocery store in Ames, Iowa. Colocasia esculenta plants were grown from small ( 5 to $8 \mathrm{~cm}$ long, white flesh) corms obtained from a grocery store in Des Moines, Iowa, and had green leaves and pseudopetioles. Coffee (Coffea arabica) plants were grown from seeds obtained from Sheffield's Seed Company. Cacao, sycamore, sweet potato, and coffee plants were started in shallow trays in a high-humidity mist bay for approximately 4 weeks and then transplanted into 6-inch pots in a warm greenhouse. Mango seeds and Colocasia corms were directly planted in 6-inch pots in the same greenhouse. All plants were kept in full sun, except for cacao plants, which were grown under silver shade cloth that reduced sunlight to about $20 \%$ ambient. Plants were grown in the greenhouse with adequate water for 1 to 12 months, depending on the plant species and experiment, before being transferred to growth chambers. Plants used in the threehost experiment received weekly applications of fertilizer $(25 \%$ Peter's Excel 21-5-20, 75\% Peter's Cal-Mag Special 15-5-15) prior to and throughout each experiment; plants used in other experiments received weekly applications of Miracle Gro Excel 215-20 only prior to being moved to the growth chambers.

Cacao plants used in the three-host experiment were 6 months old; those used in the cacao inoculation were 4 to 5 months old. Sweet potato plants in the three-host experiment were 3 to 5 weeks old, and those used in the five-host experiment were 8 to 12 weeks old. Sycamore plants used in the three-host experiment were 4 months old, and those used in the five-host experiment were 6 months old. Mango plants were 12 months old, coffee plants were 7 months old, and Colocasia plants were 3 months old.

Seven days prior to inoculation, the potted plants were moved to a growth chamber set at $25^{\circ} \mathrm{C}$ with $16 / 8$-h light/dark cycle and illumination of about $110 \mu \mathrm{mol} \mathrm{cm} \mathrm{cm}^{-2} \mathrm{~s}^{-1}$ of photosynthetically active radiation. High humidity was maintained with trays of water inside the chamber, except in the cacao inoculation experiment, which utilized a growth chamber with automatic humidity control (65 to $80 \%$ relative humidity). Each growth chamber experiment used a balanced, completely random design, in which individual plants were assigned to treatments and arranged in the growth chamber randomly, with five plants per treatment and five plants as control (except for one sycamore experiment, with six plants per treatment). All growth chamber experiments were repeated except for the inoculations of sweet potato, sycamore, and mango in the five-host inoculation experiment.

Inoculum was prepared from self-fertile, single-ascospore progeny of each isolate grown on malt yeast extract agar (MYEA; 2\% malt extract, $2 \%$ agar, and $0.2 \%$ yeast extract) at room temperature for 7 days. Each culture was flooded with $10 \mathrm{ml}$ of sterile deionized water and scraped with a sterile spatula, and the resulting spore suspension was filtered through four layers of sterile cheesecloth, which was then rinsed with an additional $5 \mathrm{ml}$ of water. The concentration of the spores was estimated with a hemacytometer, diluted to $2.0 \times 10^{5}$ spores per $\mathrm{ml}$, and loaded into sterile syringes (needle gauge 21). Spore suspensions consisted almost entirely of cylindrical endoconidia, although there were also some ascospores, aleurioconidia, and hyphal fragments. Controls were prepared by flooding and scraping a sterile MYEA plate.

Sweet potato plants were wounded by a sterile dissection needle used to punch a hole through each stem about $3 \mathrm{~cm}$ above the soil line. The pseudopetiole of the youngest, fully expanded leaf of each Colocasia plant was similarly wounded. For the woody plants, an approximately $3 \mathrm{~mm}$ deep, downward-slanting cut was made from the outer bark to the inner wood with a sterile scalpel, approximately $3 \mathrm{~cm}$ from the base of the plant. Each wound was injected with at least $0.2 \mathrm{ml}$ of spore suspension with the syringe, and the inoculation site was wrapped in Parafilm. In the three-host inoculation experiment, plant height was recorded immediately before inoculation and at harvest. Plants were observed daily and harvested either when they died (no fleshy green leaf tissue present) or at 45 days (three-host experiment) or 28 days (all other experiments) after inoculation.

At harvest, each stem was sliced open vertically above and below the point of inoculation, and the length of xylem discoloration was recorded. To reisolate the fungus, discolored tissue was placed between slices of carrot and incubated under humid condi- 


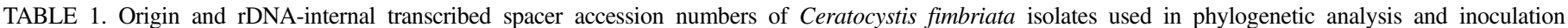
experiments

\begin{tabular}{|c|c|c|c|c|c|}
\hline Isolate & Other number ${ }^{\mathrm{x}}$ & GenBank Accession No. & Host plant & Location collected & Inoculation experiment ${ }^{\mathrm{y}}$ \\
\hline C940 & CBS 152.62 & AY157951 & Cacao & Costa Rica & GC3 \\
\hline C 1547 & & & Cacao & Costa Rica & GC3, GCC, CRC \\
\hline $\mathrm{C} 1548$ & & AY157952 & Cacao & Costa Rica & $\mathrm{GC} 3, \mathrm{GC} 5, \mathrm{GCC}, \mathrm{CR} 3, \mathrm{CRC}$ \\
\hline C1549 & & & Cacao & Costa Rica & $\mathrm{CRC}$ \\
\hline $\mathrm{C} 1550$ & & & Cacao & Costa Rica & $\mathrm{CRC}$ \\
\hline C1634 & & & Cacao & Costa Rica & CR3, CRC \\
\hline $\mathrm{C} 1635$ & & & Cacao & Costa Rica & $\mathrm{CRC}$ \\
\hline C1636 & & & Cacao & Costa Rica & $\mathrm{CRC}$ \\
\hline $\mathrm{C} 1637$ & & & Cacao & Costa Rica & $\mathrm{CRC}$ \\
\hline $\mathrm{C} 1638$ & & & Cacao & Costa Rica & CRC \\
\hline C1639 & & & Cacao & Costa Rica & CR3, CRC \\
\hline $\mathrm{C} 1640$ & & & Cacao & Costa Rica & CR3, CRC \\
\hline $\mathrm{C} 1642$ & & & Herrania sp. & Costa Rica & CRC \\
\hline $\mathrm{C} 1778$ & & & Herrania sp. & Costa Rica & \\
\hline $\mathrm{C} 1587$ & & AY157953 & Cacao & Brazil & $\mathrm{GCC}, \mathrm{Br}$ \\
\hline C1593 & & & Cacao & Brazil & $\mathrm{GCC}, \mathrm{Br}$ \\
\hline C1596 & & & Cacao & Brazil & \\
\hline C1597 & & & Cacao & Brazil & $\mathrm{Br}$ \\
\hline $\mathrm{C} 1600$ & & & Cacao & Brazil & \\
\hline C1004 & CBS 153.62 & AY157950 & Cacao & Ecuador & $\mathrm{GCC}$ \\
\hline C1690 & & & Cacao & Ecuador & $\mathrm{GCC}$ \\
\hline C1691 & & & Cacao & Ecuador & \\
\hline C1695 & & & Cacao & Ecuador & \\
\hline C1696 & & & Cacao & Ecuador & GCC \\
\hline C1751 & & & Cacao & Ecuador & GCC \\
\hline C1756 & & & Cacao & Ecuador & \\
\hline C1833 & & & Cacao & Ecuador & \\
\hline C1834 & & & Cacao & Ecuador & GCC \\
\hline $\mathrm{C} 1831$ & & & Cacao & Ecuador & GCC \\
\hline C1832 & & & Cacao & Ecuador & GCC \\
\hline $\mathrm{C} 1835$ & & & Cacao & Ecuador & \\
\hline C1836 & & & Cacao & Ecuador & GCC \\
\hline C1584 & & AY157954 & Cacao & Trinidad & GCC \\
\hline $\mathrm{C} 1750$ & & AY 157955 & Cacao & Columbia & $\mathrm{GCC}$ \\
\hline C1354 & & & Sweet potato & Japan & GC3 \\
\hline C1390 & IFO 30501 & & Sweet potato & Japan & \\
\hline C1869 & & & Sweet potato & Japan & \\
\hline C854 & & & Sweet potato & Louisiana, USA & \\
\hline C926 & CBS 141.37 & & Sweet potato & New Jersey, USA & \\
\hline $\mathrm{C} 1418$ & & AY157956 & Sweet potato & North Carolina, USA & GC3, GC5 \\
\hline C1484 & ATCC 13323 & & Sweet potato & Maryland, USA & \\
\hline $\mathrm{C} 1475$ & ICMP 1731 & & Sweet potato & New Zealand & \\
\hline $\mathrm{C} 1476$ & ICMP 8579 & AY157957 & Sweet potato & Papua New Guinea & GC3 \\
\hline C1932 & DAR 58857 & & Sweet potato & Papua New Guinea & \\
\hline C858 & & & Sycamore & California, USA & \\
\hline C859 & & & Sycamore & California, USA & \\
\hline C1818 & & & Sycamore & California, USA & \\
\hline C1819 & & & Sycamore & California, USA & \\
\hline C1820 & & & Sycamore & California, USA & \\
\hline $\mathrm{C} 1830$ & & & Sycamore & California, USA & \\
\hline C809 & & & Sycamore & Italy & \\
\hline $\mathrm{C} 812$ & & & Sycamore & Italy & \\
\hline $\mathrm{C} 1351$ & & & Sycamore & Kentucky, USA & GC3 \\
\hline $\mathrm{C} 1317$ & & AY157958 & Sycamore & North Carolina, USA & GC3, GC5 \\
\hline C1339 & & & Sycamore & Virginia, USA & $\mathrm{GC} 3$ \\
\hline C 1543 & & AY157961 & Coffee & Columbia & GC5 \\
\hline C1490 & & & Coffee & Costa Rica & CR3 \\
\hline C1491 & & & Coffee & Costa Rica & CR3 \\
\hline C1493 & & & Coffee & Costa Rica & CR3 \\
\hline C 1551 & & AY157962 & Coffee & Costa Rica & GC5, CR3 \\
\hline $\mathrm{C} 1005$ & CBS 103.40 & AY 157960 & Coffee & Guatemala & GC5 \\
\hline C996 & CBS 146.53 & AY 157959 & Coffee & Suriname & GC5 \\
\hline $\mathrm{C} 1641$ & & AY 157963 & Xanthosoma sp. & Costa Rica & $\mathrm{GC} 5, \mathrm{CR} 3$ \\
\hline C994 & CBS 600.70 & AY 157964 & Mango & São Paulo state, Brazil & $\mathrm{GC} 5, \mathrm{Br}$ \\
\hline $\mathrm{C} 1558$ & & AY 157965 & Mango & Rio de Janeiro state, Brazil & $\mathrm{GC} 5, \mathrm{Br}$ \\
\hline C1591 & & & Mango & Rio de Janeiro state, Brazil & $\mathrm{Br}$ \\
\hline $\mathrm{C} 1592$ & & & Annona sp. & Rio de Janeiro state, Brazil & $\mathrm{Br}$ \\
\hline C1603 & & & Cassava $^{\mathrm{z}}$ & Rio de Janeiro state, Brazil & $\mathrm{Br}$ \\
\hline $\mathrm{C} 1345$ & & AY157966 & Eucalyptus & Bahia state, Brazil & $\mathrm{GC} 5, \mathrm{Br}$ \\
\hline $\mathrm{C} 1442$ & & & Eucalyptus & Bahia state, Brazil & $\mathrm{GC} 5, \mathrm{Br}$ \\
\hline $\mathrm{C} 1451$ & & & Eucalyptus & Bahia state, Brazil & $\mathrm{Br}$ \\
\hline $\mathrm{C} 925$ & & AY157967 & Gmelina sp. & Pará, Brazil & $\mathrm{GC} 5, \mathrm{Br}$ \\
\hline
\end{tabular}

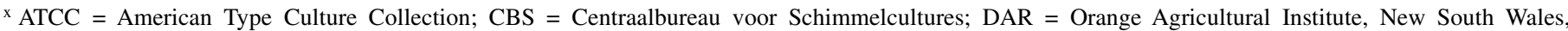
Australia; ICMP = Landcare Research New Zealand; and IFO = Institute for Fermentation, Osaka, Japan.

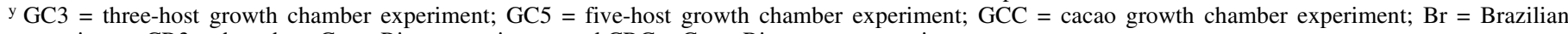
experiment; $\mathrm{CR} 3$ = three-host Costa Rican experiment; and CRC $=$ Costa Rican cacao experiment.

${ }^{\mathrm{z}}$ Isolate $\mathrm{C} 1603$ was obtained from a dead cassava stem but was not pathogenic to cassava in inoculation experiments. 
tions at room temperature (31). After 7 days, the carrot slices were observed for growth of Ceratocystis fimbriata. Representative isolates (at least two per host plant per source of inoculum) were subcultured from these samples and fingerprinted (using PstI restriction enzyme and (CAT) $)_{5}$ as a probe [10]), and the banding patterns were compared with those of the original strains used in the inoculations.

Brazilian experiments. Two separate inoculation experiments were conducted using plants grown in plastic bags or pots filled with soil in an outdoor nursery on the campus of the Universidade Federal de Viçosa during June to July 2000 and March to April 2001. The first experiment included cacao seedlings (cv. Theobahia, 4-month-old), mango seedlings (cv. Espada, 5-month-old), eucalyptus cuttings $(E$. urophyla $\times$ E. grandis hybrid, 3-monthold), Crotalaria juncea L. seedlings (8-week-old), rubber seedlings (5-month-old), cassava cuttings (Manihot esculenta Crantz., 3-month-old), and coffee seedlings (Coffea arabica, 4-month-old). Mango, coffee, rubber, and cacao were grown under shade, cassava and Eucalyptus plants were grown in full sun, and Crotalaria plants were grown in partial shade. There were one to three Crotalaria plants in each pot, but each plant was inoculated separately (with the same isolate) and treated as a replicate. This experiment used an unbalanced, completely random design with approximately equal numbers of plants inoculated by each isolate. Due to the different numbers of plants available, number of replicates per treatment per plant species varied from 2 or 3 (mango) to 27 (Crotalaria plants). Plants were inoculated with 12 isolates collected in Brazil from various hosts (Table 1) by the same method as the growth chamber inoculations. Length of xylem discoloration was recorded after 22 to 23 days. We did not attempt to reisolate the fungus from inoculated plants.

The second Brazilian experiment included cacao seedlings (cv. Theobahia, 6-to 8-week-old), eucalyptus cuttings (same clone, 5-month-old), mango seedlings (cv. Espada, 1-year-old), Crotalaria juncea seedlings (5-week-old), and G. arborea seedlings (3-month-old). Cacao plants were grown under shade before and during the experiment, whereas all other plants were grown in full sun. As in the first Brazilian experiment, there were one to three Crotalaria plants per pot. Each plant species was treated as a block, and plants were inoculated by the isolates in a randomly selected order. Plants were inoculated with 11 of the same isolates as the first Brazilian experiment (Table 1), using the same method as the growth chamber inoculations, except the spore concentration was $1.0 \times 10^{6}$ spores per ml. Length of xylem discoloration was recorded after 32 to 34 days. We did not attempt to isolate the fungus from the inoculated plants.

Costa Rican experiments. Cacao seedlings (Forastero type), coffee seedlings (Coffea arabica cv. Caturra), and Xanthosoma sagittifolium (L.) Schott. plants were grown in plastic bags of soil in an outdoor nursery at the Centro Agronómico Tropical de Investigación y Enseñanza (CATIE) in Turrialba, Costa Rica. Cacao and Xanthosoma plants were 2 to 3 months old and coffee plants were 4 to 5 months old when inoculated in March 2001. Four isolates from each of cacao and coffee, and one isolate from Xanthosoma sp., all collected in Costa Rica, were inoculated into these three hosts by methods identical to those used in the growth chamber inoculations.

In a second experiment, 12 Costa Rican isolates from cacao were tested on 2- to 3-month-old cacao plants by methods identical to the growth chamber experiments. In both Costa Rican experiments, the plants were randomly assigned to treatments, 9 or 10 plants per isolate, in a completely random design. Xylem discoloration was recorded at 18 days (cacao plants) or 19 days (coffee and Xanthosoma plants) after inoculation.

Statistical analysis. For the three-host inoculation experiment, length of xylem discoloration was analyzed by inoculated host plant, source (host) of inoculum, experiment, and the host-source of inoculum interaction using a multifactorial analysis of variance
(ANOVA). Height growth of plants that survived to the end of the experiment was also analyzed by source of inoculum using an ANOVA, with each host species analyzed separately because of widely varying height growth among species. When ANOVA indicated significant variation among sources of inoculum $(P \leq 0.05)$, Duncan's multiple range test was used to separate means. The proportions of plants killed and reisolation success for each source of inoculum were compared within each host species using chisquare tests adjusted for multiple comparisons by the Bonferroni method (39).

For all other experiments, length of xylem discoloration was analyzed for each inoculated host species separately. When ANOVA indicated that the variation among isolates was significant $(P \leq 0.05)$, Duncan's multiple range test was used to separate means. For the Brazilian experiment, a multifactorial ANOVA also was used to analyze length of xylem discoloration by host species, isolate, experiment, and host-isolate and host-isolate-experiment interactions, using only data from host species that were inoculated in both experiments. All statistics were performed using SAS version 8.2 statistical software (SAS Institute, Cary, NC).

\section{RESULTS}

Phylogenetic analysis. The ITS sequences of the Ceratocystis fimbriata isolates were extremely variable, primarily due to numerous insertions and deletions (indels) in ITS1 and ITS2. There were 923 most parsimonious trees of 219 steps derived from 52 parsimony-informative positions and 98 variable but not parsimony-informative positions. Most of the variable sites that were not parsimony-informative were between the outgroup taxon (Ceratocystis albofundus) and the ingroup (Latin American clade of Ceratocystis fimbriata). The consistency index (CI), retention index (RI), and rescaled consistency (RC) index were 0.772, 0.919 , and 0.709 , respectively. Most isolates from cacao or the closely related Herrania spp. fell into a strongly supported lineage with two sublineages; one sublineage contained isolates from Ecuador and one isolate from Costa Rica, and the other sublineage contained Costa Rican and Brazilian isolates (Fig. 1). Six cacao isolates from Ecuador, Columbia, and Trinidad did not group into either of these cacao sublineages, nor did they group with each other. All sycamore isolates formed a strongly supported lineage of similar ITS sequences. Isolates from sweet potato all shared a unique ITS sequence, and the ITS sequence of isolate C1005 from a coffee plant in Guatemala was identical to that of the sweet potato strains, except for two one-base insertions. There was no bootstrap support for the clade containing isolate C1005 and the sweet potato isolates.

Because the ITS sequence of coffee isolate C1005 was very similar to that of the sweet potato isolates, we performed a separate analysis using sequences of all isolates except C1005. In this analysis, 26,623 most parsimonious trees with lengths of 217 were found. The CI, RI, and RC were 0.779, 0.921, and 0.717, respectively. Bootstrap analysis was restricted to a maximum of 100 trees for 1,000 replications due to the large number of most parsimonious trees. Bootstrap values for branches were nearly identical (no more than four percent points different) to those shown in Figure 1 (when C1005 was included), except that a branch containing all the sweet potato isolates had $79 \%$ bootstrap support, and a branch containing isolates C1442 and C1451 from Brazilian Eucalyptus spp. had $53 \%$ support.

We performed a third analysis in which indels were coded as present or absent and gaps were treated as missing data. This analysis yielded more than 433,000 most parsimonious trees with lengths of 171 . The CI, RI, and RC were $0.6842,0.8854$, and 0.6058 , respectively. Bootstrap analysis was again restricted to a maximum of 100 trees for 1,000 replications. Some of the branches shown in Figure 1 were not supported in this analysis, but the cacao lineage still had $75 \%$ bootstrap support, the 
Ecuadorian and Costa Rican cacao sublineages had support of 100 and $93 \%$, respectively, and the sycamore lineage had support of $94 \%$. Although the sweet potato isolates all had the same unique ITS sequence, there was no bootstrap support for this branch.

Growth chamber experiments. Because the ANOVA indicated no significant difference between the two three-host growth chamber experiments (Table 2), these were combined for analysis. Ceratocystis fimbriata isolates from the cacao, sweet potato, and sycamore lineages caused dramatically more xylem discoloration on the hosts from which they were originally isolated than on the other two plant species (Fig. 2). For each of the three hosts, inoculation by isolates from the other two hosts did not result in xylem discoloration significantly different from the control inoculations, which had a very small amount of discoloration, a host response to the wounding. Discoloration was not qualitatively different among the inoculated and control plants. An ANOVA of these discoloration data showed that the largest source of variation was the host-source of inoculum interaction (Table 2). With the exception of one sycamore plant inoculated with a cacao isolate, only cacao isolates killed cacao plants, only sweet potato isolates killed sweet potato plants, and only sycamore isolates killed sycamore plants (Table 3).

Height differences among surviving inoculated and control cacao and sycamore plants were not significant based on ANOVA,

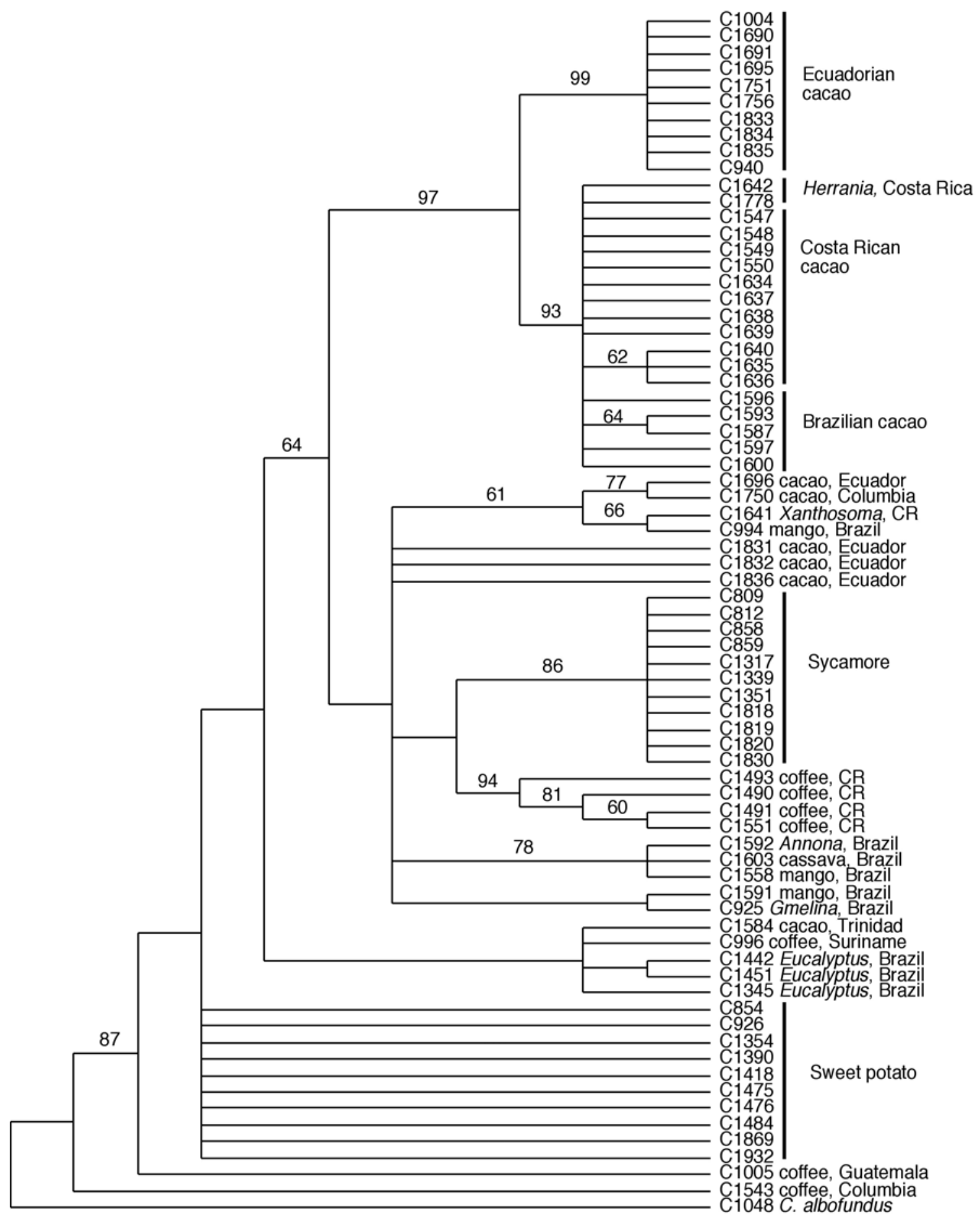

Fig. 1. Strict consensus of the 923 most parsimonious trees from a heuristic search using rDNA-internal transcribed spacer sequences from Ceratocystis fimbriata isolates of the Latin American clade. The trees are based on 586 characters, including gaps, 52 of which were parsimony-informative. Ceratocystis albofundus was used to root the tree. Bootstrap values greater than 50 are shown above the branches. 
probably because only a few plants inoculated with compatible isolates survived to the end of the experiment. However, the ANOVA of height growth of surviving sweet potato plants showed significant variation $(F=4.39 ; P=0.0062)$. The 25 surviving sweet potato plants inoculated with sweet potato isolates had reduced growth compared with sweet potato plants inoculated with cacao isolates, sycamore isolates, or the control plants (Table 3).

Reisolation of Ceratocystis fimbriata was attempted from all inoculated and control plants, but the fungus was not recovered from control plants. Reisolation success varied significantly with source of inoculum from inoculated cacao plants $(F=14.98 ; P=$

TABLE 2. Analysis of variance of the linear extent in xylem discoloration in cacao, sweet potato, and sycamore plants inoculated with Ceratocystis fimbriata isolates from these hosts

\begin{tabular}{lcrrr}
\hline Source & df & Mean square & $F$ value & \multicolumn{1}{c}{$P$} \\
\hline Host & 2 & 33.6532 & 13.55 & $<0.0001$ \\
Source of inoculum & 2 & 17.6247 & 7.10 & 0.0010 \\
Host $\times$ source of inoculum & 4 & 775.7112 & 156.19 & $<0.0001$ \\
Experiment & 1 & 0.8588 & 0.69 & 0.4063 \\
\hline
\end{tabular}

$0.0003)$ and from inoculated sycamore plants $(F=23.09 ; P<$ $0.0001)$, but not from inoculated sweet potato plants $(F=1.37$; $P=0.2852)$. Cacao isolates inoculated into cacao plants were reisolated from $73 \%$ of the seedlings, and sycamore isolates inoculated into sycamore plants were reisolated from $97 \%$ of the seedlings (Table 3). Cacao isolates were reisolated from $67 \%$ of the inoculated sycamore plants, even though these sycamore plants did not differ significantly from control plants in percent mortality, length of xylem discoloration, or height growth. The $(\mathrm{CAT})_{5}$ DNA fingerprints of cultures reisolated from the plants matched those of the original isolates (data not shown).

To see whether a wider range of Ceratocystis fimbriata isolates and host plants would show similar patterns of strong host specificity, we inoculated 13 isolates (Table 1) of diverse ITS sequences into coffee, Colocasia, sweet potato, and sycamore in a five-host growth chamber experiment. Four isolates were also inoculated into mango. Separate ANOVAs of the extent of xylem discoloration showed significant variation $(P \leq 0.05)$ among isolates on each host, but no difference between the two experiments $(P=0.6019)$. Only the sweet potato isolate caused significant discoloration on sweet potato (Table 4). Isolates from cacao, coffee,

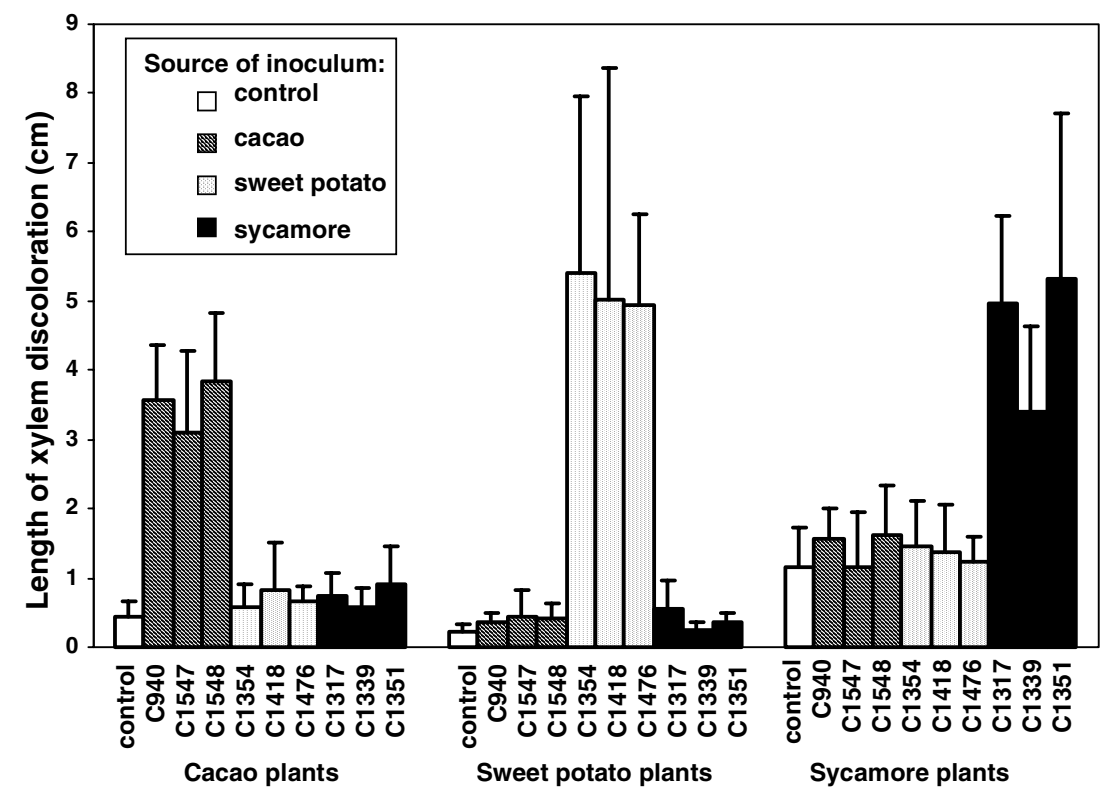

Fig. 2. Average length (centimeters) of xylem discoloration caused by nine Ceratocystis fimbriata isolates 45 days after inoculation into cacao, sweet potato, and sycamore plants. Data are means of all replicates (10 for sweet potato and cacao plants and 11 for sycamore plants) from two experiments; error bars represent standard deviation.

TABLE 3. Percent mortality, average growth in height of surviving plants 45 days after inoculation, and percent successful reisolation of isolates from the three hosts

\begin{tabular}{|c|c|c|c|c|c|}
\hline Inoculated host & Source of inoculum & No. of inoculated plants & Percent mortality ${ }^{\mathrm{z}}$ & $\begin{array}{l}\text { Average height growth } \\
\text { of survivors }(\mathrm{cm})^{\mathrm{z}}\end{array}$ & Percent reisolated ${ }^{\mathrm{z}}$ \\
\hline \multirow[t]{3}{*}{ Cacao } & Cacao & 30 & $93.3 \mathrm{a}$ & 1.0 & $73.3 \mathrm{a}$ \\
\hline & Sweet potato & 30 & $0 \mathrm{~b}$ & 1.3 & $0 \mathrm{~b}$ \\
\hline & Control & 10 & $0 \mathrm{~b}$ & 1.4 & $0 \mathrm{~b}$ \\
\hline \multirow[t]{3}{*}{ Sweet potato } & Cacao & 30 & $0 \mathrm{a}$ & $80.0 \mathrm{a}$ & $13.3 \mathrm{a}$ \\
\hline & Sweet potato & 30 & $16.7 \mathrm{a}$ & $44.8 \mathrm{~b}$ & $6.7 \mathrm{a}$ \\
\hline & Sycamore & 30 & $0 \mathrm{a}$ & $89.4 \mathrm{a}$ & $0 \mathrm{a}$ \\
\hline \multirow{3}{*}{ Sycamore } & Sweet potato & 33 & $0 \mathrm{~b}$ & 23.9 & $10.0 \mathrm{c}$ \\
\hline & Sycamore & 33 & $69.7 \mathrm{a}$ & 21.0 & $97.0 \mathrm{a}$ \\
\hline & Control & 11 & $0 \mathrm{~b}$ & 25.0 & $0 \mathrm{c}$ \\
\hline
\end{tabular}

${ }^{\mathrm{z}}$ Numbers within a column followed by the same letter within a host plant group are not significantly different according to Duncan's multiple range test (average growth; mean square error $=2,298 ; P \leq 0.05$ ) or chi-square tests (percent mortality and percent reisolated, Bonferroni adjusted $\alpha=0.0083$ ). All statistical tests were performed separately for each host plant, with three isolates for each source of inoculum and 10 or 11 replicates per isolate. An initial analysis of variance did not indicate significant differences in height growth among cacao or sycamore plants. 
and mango caused more discoloration on sycamore plants than did the control, but the sycamore isolate caused a significantly greater amount of discoloration than did the other isolates. All isolates caused more discoloration on coffee than did the control, but a coffee isolate from Costa Rica caused the greatest amount of discoloration. Only an Xanthosoma isolate caused significant discoloration on Colocasia plants (both are members of the family Araceae), and only a mango isolate did so on mango plants.

To see if all isolates from cacao were pathogenic to cacao plants, a third growth chamber experiment utilized representative isolates from the two cacao sublineages and all other cacao isolates (Fig. 1; Table 1). Amount of xylem discoloration on inoculated cacao plants varied significantly by isolate $(F=44.49 ; P<$ $0.0001)$, experiment $(F=39.86 ; P<0.0001)$, and isolate-experiment interaction $(F=4.16 ; P<0.0001)$, so experiments were analyzed separately. In both experiments, all isolates of the two cacao sublineages, except C1004, caused significantly more discoloration than the other cacao isolates, which did not differ from the controls (Table 5). Isolate C1004 appeared to be debilitated because it produced an abnormal white, fluffy mycelium in culture and did not produce perithecia. When only isolates of the cacao sublineages were analyzed (but without the nonpathogenic C1004), the ANOVA indicated no significant variation in lesion size among isolates when experiments were combined $(F=1.82$;
$P=0.1113)$ and no isolate-experiment interaction $(F=0.57$; $P=0.7546)$.

Brazilian inoculations. Considering only plant species that were inoculated in both experiments, the amount of discoloration differed significantly between experiments according to ANOVA $(P<0.0001)$. There was also a significant host-isolate-experiment interaction $(P=0.0001)$. Thus, each experiment and host species was analyzed separately (Table 6). In the first experiment, there was no xylem discoloration in any of the inoculated or control cassava plants. Lesion length in coffee and rubber was small ( 0 to $1.4 \mathrm{~cm}$ and 0 to $1.1 \mathrm{~cm}$, respectively) and did not vary among isolates and controls in the ANOVA $(P=0.1636$ and $P=0.4455$, respectively). Because of this, cassava, coffee, and rubber were not included in the second experiment.

In the first experiment, only the three cacao isolates caused more discoloration in cacao plants than the controls (Table 6). Two isolates from mango, two genetically similar isolates from cassava and Annona spp. (Fig. 1), and the Gmelina isolate all caused significant discoloration in inoculated mangos. Only isolates $\mathrm{C} 1345$ and $\mathrm{C} 1442$, both from Eucalyptus spp., caused significant discoloration on inoculated Eucalyptus plants. Crotalaria plants had the most discoloration of any of the inoculated plants and were significantly discolored by all isolates, except C1451 from Eucalyptus sp., although cacao isolates caused significantly less discoloration on inoculated Crotalaria plants than did the

TABLE 4. Mean xylem discoloration (centimeters) caused by Ceratocystis fimbriata isolates inoculated into five host plants in a growth chamber ${ }^{\mathrm{Z}}$

\begin{tabular}{|c|c|c|c|c|c|c|}
\hline Isolate & Source of isolate & Sweet potato & Sycamore & Coffee & Colocasia & Mango \\
\hline $\mathrm{C} 1548$ & Cacao, Costa Rica & $0.4 \mathrm{~b}$ & $1.4 \mathrm{bc}$ & $1.0 \mathrm{~d}-\mathrm{f}$ & $0.6 \mathrm{~b}$ & NT \\
\hline C1418 & Sweet potato, North Carolina & $4.3 \mathrm{a}$ & $0.7 \mathrm{~cd}$ & $1.2 \mathrm{c}-\mathrm{f}$ & $0.4 \mathrm{~b}$ & $1.0 \mathrm{~b}$ \\
\hline C1317 & Sycamore, North Carolina & $0.4 \mathrm{~b}$ & $5.5 \mathrm{a}$ & $1.1 \mathrm{~d}-\mathrm{f}$ & $0.6 \mathrm{~b}$ & NT \\
\hline C1641 & Xanthosoma sp., Costa Rica & $0.4 \mathrm{~b}$ & $0.7 \mathrm{~cd}$ & $0.9 \mathrm{f}$ & $3.5 \mathrm{a}$ & NT \\
\hline C1543 & Coffee, Columbia & $0.9 \mathrm{~b}$ & $0.8 \mathrm{~cd}$ & $1.8 \mathrm{~b}$ & $0.4 \mathrm{~b}$ & NT \\
\hline C1551 & Coffee, Costa Rica & $0.5 \mathrm{~b}$ & $1.9 \mathrm{~b}$ & $3.8 \mathrm{a}$ & $0.4 \mathrm{~b}$ & $0.7 \mathrm{~b}$ \\
\hline C1005 & Coffee, Guatemala & $0.4 \mathrm{~b}$ & $0.7 \mathrm{~cd}$ & 0.9 ef & $0.3 \mathrm{~b}$ & NT \\
\hline C996 & Coffee, Surinam & $0.5 \mathrm{~b}$ & $1.0 \mathrm{~cd}$ & $1.3 \mathrm{c}-\mathrm{f}$ & $0.5 \mathrm{~b}$ & NT \\
\hline C994 & Mango, Brazil & $0.4 \mathrm{~b}$ & $2.0 \mathrm{~b}$ & $1.5 \mathrm{bc}$ & $0.3 \mathrm{~b}$ & NT \\
\hline $\mathrm{C} 1558$ & Mango, Brazil & $0.4 \mathrm{~b}$ & $0.9 \mathrm{~cd}$ & $1.3 \mathrm{c}-\mathrm{f}$ & $1.0 \mathrm{~b}$ & $11.6 \mathrm{a}$ \\
\hline C1345 & Eucalyptus, Brazil & $0.3 \mathrm{~b}$ & $1.0 \mathrm{~cd}$ & $1.4 \mathrm{~b}-\mathrm{d}$ & $0.8 \mathrm{~b}$ & NT \\
\hline C1442 & Eucalyptus, Brazil & $0.3 \mathrm{~b}$ & $1.0 \mathrm{~cd}$ & $1.4 \mathrm{~b}-\mathrm{d}$ & $0.6 \mathrm{~b}$ & NT \\
\hline $\mathrm{C} 925$ & Gmelina arborea, Brazil & $0.6 \mathrm{~b}$ & $1.0 \mathrm{~cd}$ & $1.3 \mathrm{c}-\mathrm{e}$ & $0.4 \mathrm{~b}$ & NT \\
\hline Control & & $0.5 \mathrm{~b}$ & $0.5 \mathrm{~d}$ & $0.3 \mathrm{~g}$ & $0.3 \mathrm{~b}$ & $0.4 \mathrm{~b}$ \\
\hline
\end{tabular}

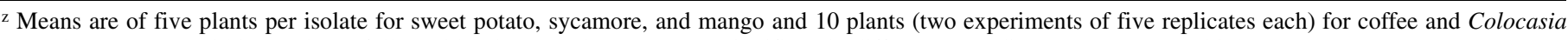
esculenta. Means within a column followed by the same letters are not significantly different according to Duncan's multiple range test (mean square error $=$ 0.25 for sweet potato, 0.34 for sycamore, 0.19 for coffee, 1.11 for Colocasia esculenta, and 7.37 for mango; $P \leq 0.05$ ). Each plant host was analyzed separately. NT = not tested.

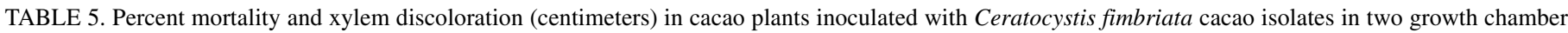
experiments $^{\mathrm{z}}$

\begin{tabular}{|c|c|c|c|c|c|c|}
\hline \multirow[b]{2}{*}{ Isolate } & \multirow[b]{2}{*}{ Country of origin } & \multirow{2}{*}{$\begin{array}{l}\text { Internal transcribed } \\
\text { spacer lineage }\end{array}$} & \multicolumn{2}{|c|}{ Experiment 1} & \multicolumn{2}{|c|}{ Experiment 2} \\
\hline & & & Percent mortality & Xylem discoloration & Percent mortality & Xylem discoloration \\
\hline $\mathrm{C} 1690$ & Ecuador & Cacao-Ecuador & 100 & $6.4 \mathrm{a}$ & 100 & $9.9 \mathrm{ab}$ \\
\hline C1547 & Costa Rica & Cacao-Costa Rica & 80 & $6.3 \mathrm{a}$ & 60 & $8.6 \mathrm{a}-\mathrm{c}$ \\
\hline C 1587 & Brazil & Cacao-Costa Rica & 100 & $6.3 \mathrm{a}$ & 100 & $10.9 \mathrm{a}$ \\
\hline C1593 & Brazil & Cacao-Costa Rica & 100 & $5.6 \mathrm{a}$ & 100 & $10.7 \mathrm{a}$ \\
\hline $\mathrm{C} 1548$ & Costa Rica & Cacao-Costa Rica & 100 & $5.4 \mathrm{a}$ & 80 & $9.4 \mathrm{a}-\mathrm{c}$ \\
\hline C1751 & Ecuador & Cacao-Ecuador & 100 & $5.1 \mathrm{a}$ & 100 & $7.4 \mathrm{c}$ \\
\hline C1834 & Ecuador & Cacao_Ecuador & 80 & $4.6 \mathrm{a}$ & 100 & $7.6 \mathrm{bc}$ \\
\hline C1004 & Ecuador & Cacao_Ecuador & 0 & $1.6 \mathrm{~b}$ & 0 & $1.0 \mathrm{~d}$ \\
\hline $\mathrm{C} 1750$ & Columbia & Other & 0 & $1.4 \mathrm{~b}$ & 0 & $1.1 \mathrm{~d}$ \\
\hline C1584 & Trinidad & Other & 0 & $1.2 \mathrm{~b}$ & 0 & $1.3 \mathrm{~d}$ \\
\hline C1832 & Ecuador & Other & 0 & $1.1 \mathrm{~b}$ & 0 & $1.6 \mathrm{~d}$ \\
\hline C1831 & Ecuador & Other & 0 & $1.1 \mathrm{~b}$ & 0 & $1.0 \mathrm{~d}$ \\
\hline C1696 & Ecuador & Other & 0 & $1.1 \mathrm{~b}$ & 0 & $1.1 \mathrm{~d}$ \\
\hline C1836 & Ecuador & Other & 0 & $1.0 \mathrm{~b}$ & 0 & $1.1 \mathrm{~d}$ \\
\hline Control & & & 0 & $1.1 \mathrm{~b}$ & 0 & $0.7 \mathrm{~d}$ \\
\hline
\end{tabular}

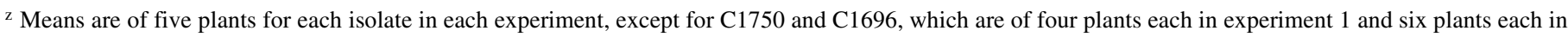
experiment 2 . Means followed by the same letter are not significantly different according to Duncan's multiple range test (experiment 1 , mean square error $=$ $2.03 ; P \leq 0.05$; and experiment 2 , mean square error $=2.88 ; P \leq 0.05$ ). 
other isolates. Isolate C1451 appeared to be debilitated in the first experiment and was not used in the second experiment.

In the second Brazilian experiment, the cacao plants were relatively young, and all cacao plants inoculated with cacao isolates died (Table 6). One cacao seedling inoculated with the Gmelina isolate also died, and among surviving cacao plants, only the Gmelina isolate caused more discoloration than did the controls. The isolates from cacao and Gmelina arborea did not cause significant discoloration on inoculated mango plants; but all three mango isolates and the related cassava and Annona isolates, and one Eucalyptus isolate caused more discoloration than the controls. As in the first Brazilian experiment, isolates C1345 and C1442 caused the most discoloration on Eucalyptus plants, although isolates from cassava, mango, and Gmelina arborea also caused more discoloration than did the controls. Substantial discoloration was found in Crotalaria plants inoculated by all isolates, and several Crotalaria plants inoculated with each isolate died. Only the Gmelina isolate caused significant xylem discoloration in Gmelina plants.

Costa Rican inoculations. The ANOVA of the extent of xylem discoloration in each of the three hosts indicated significant $(P<$ 0.0001 in each case) variation among isolates. Cacao isolates caused extensive discoloration and death in inoculated cacao plants, whereas cacao plants inoculated with coffee or Xantho- soma isolates did not differ from controls (Table 7). Only coffee plants inoculated with coffee isolates had xylem discoloration significantly greater than that of control plants, and only the Xanthosoma isolate caused significant xylem discoloration in Xanthosoma plants.

ANOVA indicated significant variation in the extent of xylem discoloration among the 12 Costa Rican cacao isolates inoculated into cacao plants and the control treatment $(F=4.49 ; P<0.0001)$. All isolates caused more xylem discoloration than did the control inoculations (Table 8). Sixty-five percent of inoculated seedlings died, and there was an average of $4.3 \mathrm{~cm}$ of discoloration in the inoculated seedlings compared with no mortality and $0.7 \mathrm{~cm}$ in control plants. However, when control inoculations were removed, there was no variation among the 12 isolates in the amount of xylem discoloration produced $(F=1.53 ; P=0.1303)$.

\section{DISCUSSION}

Analysis of rDNA-ITS sequences demonstrated substantial genetic variation and resolved some lineages within the Latin American clade of Ceratocystis fimbriata. Isolates from some of the lineages showed host specialization in a series of inoculation experiments, consistent with several previous, smaller inoculation studies $(4,9,23,38)$. The association of specific ITS sequences

TABLE 6. Mean xylem discoloration (centimeters) caused by Brazilian isolates of Ceratocystis fimbriata in inoculated cacao, mango, Eucalyptus, Crotalaria, and Gmelina seedlings in Brazily

\begin{tabular}{|c|c|c|c|c|c|c|c|c|c|c|c|c|c|c|c|c|c|c|c|}
\hline \multirow[b]{3}{*}{ Isolate } & \multirow{3}{*}{$\begin{array}{l}\text { Source } \\
\text { of isolate }\end{array}$} & \multicolumn{4}{|c|}{ Cacao } & \multicolumn{4}{|c|}{ Mango } & \multicolumn{4}{|c|}{ Eucalyptus } & \multicolumn{4}{|c|}{ Crotalaria } & \multirow{2}{*}{\multicolumn{2}{|c|}{$\begin{array}{c}\text { Gmelina } \\
\text { Exp. } 2\end{array}$}} \\
\hline & & \multicolumn{2}{|c|}{ Exp. 1} & \multicolumn{2}{|c|}{ Exp. 2} & \multicolumn{2}{|c|}{ Exp. 1} & \multicolumn{2}{|c|}{ Exp. 2} & \multicolumn{2}{|c|}{ Exp. 1} & \multicolumn{2}{|c|}{ Exp. 2} & \multicolumn{2}{|c|}{ Exp. 1} & \multicolumn{2}{|c|}{ Exp. 2} & & \\
\hline & & $\mathrm{N}$ & $\mathrm{XD}$ & $\mathrm{N}$ & $\mathrm{XD}$ & $\mathrm{N}$ & $\mathrm{XD}$ & $\mathrm{N}$ & $\mathrm{XD}$ & $\mathrm{N}$ & $\mathrm{XD}$ & $\mathrm{N}$ & $\mathrm{XD}$ & $\mathrm{N}$ & $\mathrm{XD}$ & $\mathrm{N}$ & $\mathrm{XD}$ & $\mathrm{N}$ & $\mathrm{XD}$ \\
\hline 15 & C & 8 & $4 \mathrm{a}$ & (10) & - & & $0.7 \mathrm{c}$ & 10 & $\mathrm{~d}$ & 7 & $0.9 \mathrm{c}$ & 1 & & & de & 1) & & 5 & $0.4 \mathrm{~b}$ \\
\hline C1597 & Cacao & 8 & $8.0 \mathrm{~b}$ & $0(10)$ & - & 3 & $3.2 \mathrm{bc}$ & 10 & $2.0 \mathrm{~cd}$ & 8 & $0.5 \mathrm{c}$ & 10 & 14 & 26 & $13.5 \mathrm{~d}$ & 18 (1) & & 5 & $0.4 \mathrm{~b}$ \\
\hline 1345 & Euca & 8 & $4 \mathrm{c}$ & 10 & 0.5 & 3 & $5.1 \mathrm{bc}$ & 10 & $\mathrm{cc}$ & 7 & $6.4 \mathrm{~b}$ & 10 & & 27 & & & & 5 & $0.5 \mathrm{~b}$ \\
\hline & & 7 & & , & 0.7 & 3 & $2.1 \mathrm{c}$ & 10 & 4.2 & 0 & $9.1 \mathrm{a}$ & 10 & 4.3 & & 20 & $12(5)$ & 56. & 5 & $0.9 \mathrm{~b}$ \\
\hline C994 & Mango & 0 & $0.5 \mathrm{c}$ & 10 & $6 \mathrm{bc}$ & 3 & $4.6 \mathrm{bc}$ & 10 & $8.8 \mathrm{~b}$ & 8 & $0.6 \mathrm{c}$ & 10 & $1.3 \mathrm{~b}-\mathrm{e}$ & 24 & $23.9 \mathrm{bc}$ & $10(5)$ & 42. & 5 & $0.8 \mathrm{~b}$ \\
\hline 1558 & Man & 8 & & 10 & & 3 & $8.5 \mathrm{ab}$ & 10 & 163 & 7 & $0.8 \mathrm{c}$ & 10 & & 05 & $22.7 \mathrm{c}$ & $9(8)$ & & 5 & $0.7 \mathrm{~b}$ \\
\hline & Man & 8 & & 10 & & 2 & $13.6 \mathrm{a}$ & 10 & & 0 & $1.3 \mathrm{c}$ & 10 & & & & 16( & & 5 & $0.8 \mathrm{~b}$ \\
\hline 1603 & $\mathrm{Ca}$ & 7 & $4 \mathrm{c}$ & 10 & 0. & 3 & $9.2 \mathrm{ab}$ & 10 & $15.2 \mathrm{a}$ & 0 & $0.8 \mathrm{c}$ & 10 & 2.6 & 25 & $35.9 \mathrm{a}$ & $7(11)$ & 44.9 & 5 & $0.6 \mathrm{~b}$ \\
\hline C925 & Gmelina sp. & 8 & $1.3 \mathrm{c}$ & $9(1)$ & $1.4 \mathrm{a}$ & 3 & $8.3 \mathrm{ab}$ & 10 & $2.5 \mathrm{~cd}$ & 8 & $0.7 \mathrm{c}$ & 10 & $2.9 \mathrm{ab}$ & 26 & $37.2 \mathrm{a}$ & $6(12)$ & $71.8 \mathrm{a}$ & 5 & $8.1 \mathrm{a}$ \\
\hline $\begin{array}{l}\text { Contro } \\
\text { Mean }\end{array}$ & EIIOI & 7 & $\begin{array}{l}0.6 \mathrm{c} \\
3.07\end{array}$ & 10 & $\begin{array}{l}0.6 \mathrm{bc} \\
0.056\end{array}$ & 2 & $\begin{array}{l}0.6 \mathrm{c} \\
9.81\end{array}$ & 10 & $\begin{array}{r}0.3 \mathrm{~d} \\
22.66\end{array}$ & 8 & $\begin{array}{l}0.4 \mathrm{c} \\
4.82\end{array}$ & 10 & $\begin{array}{l}0.5 \mathrm{e} \\
2.90\end{array}$ & 27 & $\begin{array}{r}2.6 \mathrm{f} \\
145.92\end{array}$ & 15 & $\begin{array}{r}6.8 \mathrm{~g} \\
365.23\end{array}$ & 4 & $\begin{array}{l}0.6 \mathrm{~b} \\
4.03\end{array}$ \\
\hline
\end{tabular}

${ }^{y}$ Experiment 1 lasted 22 to 23 days and experiment 2 lasted 32 to 34 days. $\mathrm{N}=$ number of surviving plants used in the analysis; numbers of plants that died during experiment 2 and from which discoloration data could not be obtained are given in parentheses. XD = xylem discoloration, in centimeters; means are from all surviving plants. Means followed by the same letters within a column are not significantly different according to Duncan's multiple range test $(P \leq$ 0.05); each plant host in each experiment was analyzed separately.

${ }^{\mathrm{z}}$ Isolate C1451 was not used in experiment 2 because it appeared debilitated in experiment 1.

TABLE 7. Percent mortality and mean xylem discoloration (centimeters) caused by Costa Rican isolates of Ceratocystis fimbriata in inoculated cacao, coffee, and Xanthosoma plants in Costa Rica ${ }^{2}$

\begin{tabular}{|c|c|c|c|c|c|c|c|}
\hline \multirow[b]{2}{*}{ Isolate } & \multirow{2}{*}{$\begin{array}{l}\text { Source } \\
\text { of isolate }\end{array}$} & \multicolumn{2}{|c|}{ Cacao } & \multicolumn{2}{|c|}{ Coffee } & \multicolumn{2}{|c|}{ Xanthosoma sagittifolium } \\
\hline & & Percent mortality & Xylem discoloration & Percent mortality & Xylem discoloration & Percent mortality & Xylem discoloration \\
\hline C1640 & Cacao & 60 & $6.0 \mathrm{a}$ & 0 & $0.0 \mathrm{~d}$ & 0 & $0.7 \mathrm{~b}$ \\
\hline C1639 & Cacao & 80 & $4.7 \mathrm{~b}$ & 0 & $0.0 \mathrm{~d}$ & 11 & $0.7 \mathrm{~b}$ \\
\hline C1634 & Cacao & 60 & $3.4 \mathrm{c}$ & 0 & $0.0 \mathrm{~d}$ & 0 & $0.7 \mathrm{~b}$ \\
\hline C1490 & Coffee & 0 & $0.8 \mathrm{~d}$ & 0 & $1.4 \mathrm{a}$ & 0 & $0.7 \mathrm{~b}$ \\
\hline C1491 & Coffee & 0 & $0.8 \mathrm{~d}$ & 0 & $1.0 \mathrm{bc}$ & 0 & $0.6 \mathrm{~b}$ \\
\hline C1641 & Xanthosoma sp. & 0 & $0.8 \mathrm{~d}$ & 0 & $0.0 \mathrm{~d}$ & 100 & $10.8 \mathrm{a}$ \\
\hline Control & & 0 & $0.6 \mathrm{~d}$ & 0 & $0.0 \mathrm{~d}$ & 0 & $0.5 \mathrm{~b}$ \\
\hline
\end{tabular}

${ }^{\mathrm{z}}$ Means are of 10 plants per isolate for most isolates (nine per isolate for isolates C1639 and C1640 in both coffee and Xanthosoma sagittifolium). Means followed by the same letters within a column are not significantly different according to Duncan's multiple range test (mean square error $=1.47$ for cacao, 0.12 for coffee, and 4.79 for Xanthosoma sagittifolium; $P \leq 0.05$ ); each plant host was analyzed separately. Percent mortality of cacao or coffee plants or inoculated pseudopetiole/leaf of Xanthosoma sagittifolium. 
with host specialization suggests that some genotypes of Ceratocystis fimbriata have adapted to specific hosts.

Host susceptibility. The inoculation experiments provided generally consistent results despite differences in plant age, cultivars, and growth chamber and nursery conditions. Wounds on the trunk or branches are the most common infection court for natural infections of woody hosts, so the inoculation method used closely approximated natural conditions. Differences between the results of the two Brazilian experiments may be partly due to different ages of plants and experiments of different duration. Generally, there was more discoloration and mortality in the second experiment, which was harvested after 32 to 34 days rather than 22 to 23 days. However, the trends in host susceptibility were consistent for hosts such as cacao that were used in both growth chamber and nursery inoculations.

Many of the hosts not native to the Americas were susceptible to isolates from many hosts. For example, in the Brazilian inoculation study, all isolates tested caused more discoloration in Crotalaria plants than did the control inoculations, and all but the cacao isolates and one Eucalyptus isolate caused more discoloration in mango than did the controls. In growth chamber experiments, all isolates caused more discoloration in coffee than did the controls. In contrast, the American hosts, cacao (54), sweet potato $(3,25)$, sycamore (42), and Xanthosoma sagittifolium (37), were highly resistant to all isolates except those from their respective hosts.

Several host resistance mechanisms may contribute to host specialization. A variety of phytoalexins are elicited in sycamore $(2,8,11-13)$ and sweet potato plants $(22,33,34,44,45,47-50)$ when challenged with Ceratocystis fimbriata. Several of these phytoalexins, especially spore agglutinating factors (26-28) and furanoterpenoid phytoalexins $(29,55)$, have been suggested to play key roles in determining host specialization of sweet potato isolates and Asian isolates from Colocasia esculenta. It is possible that phytoalexins in the discolored tissue of inoculated sweet potato plants inhibited the fungus and reduced our recovery of Ceratocystis fimbriata from those plants. Sycamore isolates of Ceratocystis fimbriata produce phytotoxins $(1,36)$, and these may also play a role in determining host specificity of the fungus. Mechanisms of resistance have not been well studied in cacao, but only cacao isolates could infect and survive in cacao seedlings, suggesting that the cacao sublineages of Ceratocystis fimbriata are uniquely adapted to cacao.

Host-specialized lineages. Two strongly supported lineages delineated by the phylogenetic analysis contained only isolates from cacao and sycamore. Sweet potato isolates all shared a unique, identical ITS sequence and also formed a moderately supported lineage when a related isolate from coffee was removed from the

TABLE 8. Percent mortality and mean xylem discoloration (in centimeters) and percent mortality of cacao seedlings inoculated with Costa Rican cacao isolates

\begin{tabular}{lcc}
\hline Isolate & Percent mortality & Length of discoloration $^{\mathrm{z}}$ \\
\hline C1638 & 100 & $5.9 \mathrm{a}$ \\
C1634 & 30 & $4.7 \mathrm{ab}$ \\
C1549 & 70 & $4.7 \mathrm{ab}$ \\
C1548 & 90 & $4.5 \mathrm{ab}$ \\
C1639 & 50 & $4.5 \mathrm{ab}$ \\
C1550 & 50 & $4.4 \mathrm{ab}$ \\
C1640 & 70 & $4.3 \mathrm{ab}$ \\
C1635 & 90 & $4.2 \mathrm{ab}$ \\
C1636 & 60 & $3.9 \mathrm{~b}$ \\
C1642 & 80 & $3.7 \mathrm{~b}$ \\
C1547 & 60 & $3.2 \mathrm{~b}$ \\
C1637 & 30 & $3.1 \mathrm{~b}$ \\
Control & 0 & $0.7 \mathrm{c}$ \\
\hline
\end{tabular}

${ }^{\mathrm{z}}$ Means (of 10 plants) followed by the same letters are not significantly different according to Duncan's multiple range test (mean square error $=$ $3.30 ; P \leq 0.05)$ analysis. The isolate from Xanthosoma sp. also had a unique ITS sequence. Isolates from these four host-associated lineages were uniquely pathogenic to their respective American hosts. The cacao lineage contained two geographic sublineages, one from Ecuador and the other from Costa Rica and Brazil, but isolates of these sublineages did not differ in aggressiveness to cacao in our growth chamber inoculations. Other cacao isolates with differing ITS sequences were not pathogenic to cacao, and at least some of these isolates were not from trees with cacao wilt.

Isolates from hosts not native to Latin America (i.e., from coffee, mango, Eucalyptus spp., and Gmelina arborea) generally showed some specialization to their respective hosts, but the specialization was not as strong as that shown by isolates from the four native hosts. Coffee isolates from Guatemala, Costa Rica, Columbia, and Suriname had very different ITS sequences, and these differed in their aggressiveness to coffee. Likewise, many ITS genotypes were found among isolates from mango and Eucalyptus spp. in various locales in Brazil. Isolates collected from mango, Annona sp., and cassava in a few small farms near São Fidelis, Rio de Janeiro, Brazil had identical ITS sequences and were highly aggressive to mango. These isolates were all collected from an area where the disease was severe on mango and apparently Annona sp., but the cassava isolate was from a cut stem to be used for propagation and was not pathogenic to cassava in our inoculations.

Local populations. Because Ceratocystis fimbriata is primarily disseminated by insects $(15,21,24,32)$ and long-distance dispersal is not very efficient, we hypothesize that local populations of the fungus may become geographically isolated and can develop specialization to local, native hosts. Although these local populations may not be very aggressive to their native hosts (e.g., the cacao isolates with ITS sequences differing from those of the cacao sublineages), various exotic hosts may be seriously affected. This could explain much of the observed variation in hosts of Ceratocystis fimbriata in various regions (7). For instance, mango is known as a host only in the Mata Atlantica of Brazil, Gmelina arborea only near the mouth of the Amazon, and coffee only in Central America and northwestern South America. This study shows that these hosts are attacked by different, apparently local genotypes of the fungus.

Some local genotypes of Ceratocystis fimbriata may have been moved to other regions by humans. Ceratocystis fimbriata was originally described in 1890 on sweet potato in New Jersey (17). The sweet potato pathogen may be native to the eastern and southeastern United States, but it is also well known in Asia, New Zealand, and Papua New Guinea $(7,18)$. The ITS sequences of isolates from these locations are identical to those from the eastern United States, and we suspect that the sweet potato fungus was moved to these locations on infected storage roots. Platanus spp. are known as hosts only in the United States and now southern Europe, where Platanus spp. are the only known hosts of Ceratocystis fimbriata. Ceratocystis fimbriata does not appear to be native to Europe (7), but the Platanus pathogen may have been introduced there on crating material made from diseased trees (35). Until recently, cacao was confirmed as a host of Ceratocystis fimbriata only in Central America, the Caribbean, and northwestern South America. Although Ceratocystis fimbriata has been known on the Atlantic Coast of Brazil for many decades on mango, the disease in cacao was recognized there in 1997 (6), presumably introduced in infected cacao cuttings (18). Cacao isolate C940 was collected in Costa Rica but was similar to Ecuadorian isolates in ITS sequence; it may represent an introduction of an Ecuadorian strain into Costa Rica. Genotypes of Ceratocystis fimbriata recently have been found in Eucalyptus plantations in Africa, perhaps introduced from South America (41), and the ITS sequences of the African isolates are similar to those of Eucalyptus isolates from Brazil (T. C. Harrington and C. J. Baker, unpublished data). 
Host specialization appears to be a major factor defining other groups of closely related, morphologically indistinguishable species of Ceratocystis (20). It is likely that several of the lineages of Ceratocystis fimbriata that have adapted to American hosts represent distinct species or populations in the process of speciation. Recognition of these unique populations as species would facilitate disease management and the development of more effective quarantine measures to minimize the risk of introducing specialized forms of the pathogen to new regions. Further work will focus on intersterility barriers and phylogenetic divergence among these putative species.

\section{ACKNOWLEDGMENTS}

This research was supported by the National Science Foundation through grants DEB-987065 and DEB-0128104. We thank the companies Almirante Cacau (Itabuna, Brazil) and Veracel (Eunápolis, Brazil) and S. D. Silva (CEPLAC) for supplying cacao seeds; Bahia Sul Cellulose (Bahia, Brazil) for supplying eucalyptus cuttings; C. Suarez, C. Belezaca, E. Alvarez, B. L. Castro, J.-H. S. Damasieno, E. Furtado, and S. Silveira for providing fungal isolates or aiding in their collection; E. Zauza, R. Mafia, A. Martínez, C. Umaña, J. Johnson, J. Steimel, and D. McNew for technical assistance; and G. Munkvold for reviewing the manuscript.

\section{LITERATURE CITED}

1. Ake, S., Darbon, H., Grillet, L., and Lambert, C. 1992. Fimbriatan, a protein from Ceratocystis fimbriata. Phytochemistry 31:1199-1202.

2. Alami, I., Mari, S., and Clérivet, A. 1998. A glycoprotein from Ceratocystis fimbriata f. sp. platani triggers phytoalexin synthesis in Platanus $\times$ acerifolia cell-suspension cultures. Phytochemistry 48:771-776.

3. Austin, D. F. 1978. The Ipomoea batatas complex. I. Taxonomy. Bull. Torrey Bot. Club 105:114-129.

4. Barba, C., and Hansen, A. J. 1962. Ceratocystis fimbriata. Study of the pathogenicity of Ceratocystis fimbriata isolated from cacao, coffee, sweet potato and coconut. Cacao 7:5.

5. Barnes, I., Gaur, A., Burgess, T., Roux, J., Wingfield, B. D., and Wingfield, M. J. 2001. Microsatellite markers reflect intra-specific relationships between isolates of the vascular wilt pathogen Ceratocystis fimbriata. Mol. Plant Pathol. 2:319-325.

6. Bezerra, J. L. 1997. Ceratocystis fimbriata causing death of budded cocoa seedlings in Bahia, Brazil. Incoped Newsl. 1:6.

7. CAB International. 2001. Ceratocystis fimbriata [original text prepared by C. J. Baker and T. C. Harrington]. In: Crop Protection Compendium. $\mathrm{CAB}$ International, Wallingford, UK.

8. Clérivet, A., and Alami, I. 1999. Effects of jasmonic acid and of an elicitor from Ceratocystis fimbriata f. sp. platani on the accumulation of phytoalexins in leaves of susceptible and resistant plane trees. Plant Sci. 148:105-110.

9. Coral, F. J., Bovi, O. A., and Ribeiro, I. J. A. 1984. Ação do fungo Ceratocystis fimbriata Ell. and Halst., isolade de diversos hospedeiros, sobre mudas de cacaueiro. Bragantia 43:245-248.

10. DeScenzo, R. A., and Harrington, T. C. 1994. Use of (CAT) $)_{5}$ as a DNA fingerprinting probe for fungi. Phytopathology 84:534-540.

11. El Modafar, C., Clérivet, A., Fleuriet, A., and Macheix, J. J. 1993. Inoculation of Platanus acerifolia with Ceratocystis fimbriata f. sp. platani induces scopoletin and umbelliferone accumulation. Phytochemistry 34:1271-1276.

12. El Modafar, C., Clérivet, A., and Macheix, J. J. 1996. Flavan accumulation in stems of Platanus $\times$ acerifolia seedlings inoculated with Ceratocystis fimbriata f. sp. platani, the canker stain disease agent. Can. J. Bot. 74:1982-1987.

13. El Modafar, C., Clérivet, A., Vigouroux, A., and Macheix, J. J. 1995. Accumulation of phytoalexins in leaves of plane tree (Platanus spp.) expressing susceptibility or resistance to Ceratocystis fimbriata f. sp. platani. Eur. J. Plant Pathol. 101:503-509.

14. Felsenstein, J. 1985. Confidence limits on phylogenies: An approach using the bootstrap. Evolution 39:783-791.

15. Ferreira, F. A. 1999. Mango tree blight-Brazil. CARAPHIN News 18:10.

16. Gardes, M., and Bruns, T. D. 1993. ITS primers with enhanced specificity for basidiomycetes-Application to the identification of mycorrhizae and rusts. Mol. Ecol. 2:113-118.

17. Halsted, B. D. 1890. Some fungous diseases of the sweet potato. The black rot. Bull. New Jersey Agric. Exp. Stn. 76:7-14.

18. Harrington, T. C. 2000. Host specialization and speciation in the American wilt pathogen Ceratocystis fimbriata. Fitopatol. Bras. 25:262-263.
19. Harrington, T. C., McNew, D., Steimel, J., Hofstra, D., and Farrell, R. 2001. Phylogeny and taxonomy of the Ophiostoma piceae complex and the Dutch elm disease fungi. Mycologia 93:111-136.

20. Harrington, T. C., Pashenova, N. V., McNew, D. L., Steimel, J., and Konstantinov, M. Y. 2002. Species delimitation and host specialization of Ceratocystis laricicola and C. polonica to larch and spruce. Plant Dis. $86: 418-422$.

21. Hinds, T. E. 1972. Insect transmission of Ceratocystis species associated with aspen cankers. Phytopathology 62:221-225.

22. Inoue, H., Oba, K., Ando, M., and Uritani, I. 1984. Enzymatic reduction of dehydroipomeamarone to ipomeamarone in sweet potato root tissue infected by Ceratocystis fimbriata. Physiol. Plant Pathol. 25:1-8.

23. Ito, M. F., and Filho, A. B. 1988. Metodologia de inoculação de Ceratocystis fimbriata Ell. \& Halst. em Acacia-negra, Crotalária, Figueira e Mangueira e patogenicidade a diferentes hospedeiros. Summa Phytopathol. 14:117-135.

24. Iton, E. F. 1960. Studies on a wilt disease of cacao at River Estate. II. Some aspects of wind transmission. Pages 47-58 in: Annual Report on Cacao Research, 1959-1960. Imperial College of Tropical Agriculture, University of the West Indies, St. Augustine, Trinidad.

25. Jarret, R. L., and Austin, D. F. 1994. Genetic diversity and systematic relationships in sweetpotato (Ipomoea batatas (L.) Lam.) and related species as revealed by RAPD analysis. Genet. Resour. Crop Evol. 41:165-173.

26. Kawakita, K., and Kojima, M. 1986. Possible involvement of surface substances on germinated spores of Ceratocystis fimbriata, black rot fungus, in determination of host-parasite specificity. Agric. Biol. Chem. 50:431-436.

27. Kojima, M., Kawakita, K., and Uritani, I. 1982. Studies on a factor in sweet potato root which agglutinates spores of Ceratocystis fimbriata, black rot fungus. Plant Physiol. 69:474-478.

28. Kojima, M., and Uritani, I. 1974. The possible involvement of a spore agglutinating factor(s) in various plants in establishing host specificity by various strains of black rot fungus, Ceratocystis fimbriata. Plant Cell Physiol. 15:733-737.

29. Kojima, M., and Uritani, I. 1976. Possible involvement of furanoterpenoid phytoalexins in establishing host-parasite specificity between sweet potato and various strains of Ceratocystis fimbriata. Physiol. Plant Pathol. 8:97-111.

30. Malaguti, G. 1956. La necrosis del tronco del cacao en Venezuela. Agron. Trop. Maracay 5:207-226.

31. Moller, W. J., and DeVay, J. E. 1968. Carrot as a species-selective medium for Ceratocystis fimbriata. Phytopathology 58:123-124.

32. Moller, W. J., and DeVay, J. E. 1968. Insect transmission of Ceratocystis fimbriata in deciduous fruit orchards. Phytopathology 58:1499-1508.

33. Oba, K., Oga, K., and Uritani, I. 1982. Metabolism of ipomeamarone in sweet potato root slices before and after treatment with mercuric chloride or infection with Ceratocystis fimbriata. Phytochemistry 21:1921-1925.

34. Okumura, K., Hyodo, H., Kato, M., Ikoma, Y., and Yano, M. 1999. Ethylene biosynthesis in sweet potato root tissue infected by black rot fungus (Ceratocystis fimbriata). Postharvest Biol. Technol. 17:117-125.

35. Panconesi, A. 1999. Canker stain of plane trees: A serious danger to urban plantings in Europe. J. Plant Pathol. 81:3-15.

36. Pazzagli, L., Cappugi, G., Manao, G., Camici, G., Santini, A., and Scala, A. 1999. Purification, characterization, and amino acid sequence of Cerato-platanin, a new phytotoxic protein from Ceratocystis fimbriata $\mathrm{f}$. sp. platani. J. Biol. Chem. 274:24959-24964.

37. Plucknett, D. L. 1976. Edible aroids. Pages 4-6 in: Evolution of Crop Plants. N. W. Simmonds, ed. Longman, New York.

38. Ribeiro, I. J. A., and Coral, F. J. 1968. Estudo preliminar da ação do fungo Ceratocystis fimbriata Ell. and Halst., causador da seca da mangueira (Mangifera indica L.), sôbre cacaueiros (Theobroma cacao L.). Bragantia 27:87-89.

39. Rosner, B. 2000. Fundamentals of Biostatistics. 5th ed. Duxbury, Pacific Grove, CA.

40. Roux, J., Harrington, T. C., Steimel, J. P., and Wingfield, M. J. 2001. Genetic variation in the wilt pathogen Ceratocystis albofundus. Mycoscience 42:327-332.

41. Roux, J., Wingfield, M. J., Bouillet, J.-P., Wingfield, B. D., and Alfenas, A. C. 2000. A serious new wilt disease of Eucalyptus caused by Ceratocystis fimbriata in Central Africa. For. Pathol. 30:175-184.

42. Santamour, F. S. 1972. Interspecific hybridization in Platanus. For. Sci. 18:236-239.

43. Santini, A., and Capretti, P. 2000. Analysis of the Italian population of Ceratocystis fimbriata f. sp. platani using RAPD and minisatellite markers. Plant Pathol. 49:461-467.

44. Schneider, J. A., Lee, J., Naya, Y., Nakanishi, K., Oba, K., and Uritani, I. 1984. The fate of the phytoalexin ipomeamarone: Furanoterpenes and butenolides from Ceratocystis fimbriata-infected sweet potatoes. Phytochemistry 23:759-764. 
45. Shaodong, G., and Hesheng, L. 1995. Lipoxygenase and its role in sweet potato tubers infected by Ceratocystis fimbriata. Acta Phytopathol. Sin. 25:325-329.

46. Swofford, D. L. 2002. PAUP*: Phylogenetic Analysis Using Parsimony (and Other Methods). Version 4.0b10a. Sinauer Associates, Sunderland, MA.

47. Takeuchi, A., Oguni, I., Oba, K., Kojima, M., and Uritani, I. 1978. Interactions between diseased sweet potato terpenoids and Ceratocystis fimbriata. Agric. Biol. Chem. 42:935-939.

48. Takeuchi, A., Yamaguchi, M., and Uritani, I. 1981. ATP citrate lyase from Ipomoea batatas root tissue infected with Ceratocystis fimbriata. Phytochemistry 20:1235-1239.

49. Uritani, I. 1998. Biochemical comparison in storage: Stress response between sweet potato and cassava. Trop. Agric. 75:177-182.

50. Weber, D. J., and Stahmann, M. A. 1964. Ceratocystis infection in sweet potato: Its effect on proteins, isozymes, and acquired immunity. Science 146:929-931.
51. Webster, R. K., and Butler, E. E. 1967. A morphological and biological concept of the species Ceratocystis fimbriata. Can. J. Bot. 45:14571468.

52. White, T. J., Bruns, T., Lee, S., and Taylor, J. 1990. Amplification and direct sequencing of fungal ribosomal RNA genes for phylogenetics. Pages 315-322 in: PCR Protocols: A Guide to Methods and Application. M. A. Innis, D. H. Gelfand, J. J. Sninsky, and T. J. White, eds. Academic Press, San Diego, CA.

53. Wingfield, M. J., DeBeer, C., Visser, C., and Wingfield, B. D. 1996. A new Ceratocystis species defined using morphological and ribosomal DNA sequence comparisons. Syst. Appl. Microbiol. 19:191-202.

54. Wood, G. A. R., and Lass, R. A. 1985. Cocoa. 4th ed. Longman, New York.

55. Yasuda, K., and Kojima, M. 1986. The role of stress metabolites in establishing host-parasite specificity between sweet potato and Ceratocystis fimbriata, black rot fungus. Agric. Biol. Chem. 50:18391846. 